\title{
Antibacterial effect of Aqueous Neem (Azadirachta indica) leaf extract, crude neem leaf paste, and Ceftriaxone against Staphylococcus aureus, Escherichia coli and Pseudomonas aeruginosa
}

\author{
Shamima Sultana ${ }^{1}$, A.S.M. Shahidullah ${ }^{2}$, Md. Mahbubul Islam ${ }^{3 *}$, A.F.S.A. Wasey ${ }^{4}$, Shamsun Nahar ${ }^{5}$ \\ ${ }^{1}$ Associate Professor, Department of Pharmacology, Mymensingh Medical College, Mymensingh, BANGLADESH \\ ${ }^{2}$ Assistant Professor, Department of Community Medicine, SSNIMC, Kishoregonj, BANGLADESH \\ ${ }^{3}$ Chief Scientific Officer, Agronomy Division, Bangladesh Jute Research Institute, Manikmia Avenue, Dhaka, BANGLADESH \\ ${ }^{4}$ Consultant, Department of Microbiology/Clinical Pathology, United Hospital, Dhaka, BANGLADESH \\ ${ }^{5}$ Professor Pharmacology, Department of Pharmacology, Mymensingh Medical College, Mymensingh, BANGLADESH \\ *Correspondence (Email): \\ mahbubul_agronomy@yahoo.com
}

\begin{abstract}
The study was conducted during the period of July 2004 to June 2005 in the Department of Pharmacology \& Therapeutics in collaboration of Department of Microbiology, Mymensingh Medical College, Mymensingh to determine the profile of antibacterial effect of crude neem leaf paste (CNLP), aqueous neem leaf extract (ANLE), and standard antibiotic Ceftriaxone against Staphylococcus aureus, Escherichia coli and, Pseudomonas aeruginosa. Five separate experiments were done e.g. I) Determination of inhibitory effect of crude neem leaf paste (CNLP) by incorporation into nutrient agar media (NA), against Staphylococcus aureus, Escherichia coli and, Pseudomonas aeruginosa. II) Determination of minimum inhibitory concentration (MIC) of aqueous neem leaf extract (ANLE) against that three test organisms by broth dilution technique, III) Determination of minimum inhibitory concentration (MIC) of standard antibiotic ceftriaxcone against test organisms by broth dilution technique as well as making a comparison with MIC of ANLE and IV) Subculture study of materials from effective CNLP, ANLE, NLEE and Ceftriaxone in nutrient agar medium for confirmation of respective results of different experiments conducted. Results revealed that inhibitory effects were observed against the growth of Staph. aureus, Esch. coli and Ps. aeruginosa at 15\%, 20\% and 25\% respectively of CNLP incorporated into NA media. The broth dilution technique was followed to determine the MICs of ANLE and Ceftriaxone. The MIC of ANLE was $714 \mu \mathrm{g} / \mathrm{ml}$ against S. aureus and that against E. coli and P. aeruginosa was $1428 \mu \mathrm{g} / \mathrm{ml}$. The MIC of Ceftriaxone was $10 \mu \mathrm{g} / \mathrm{ml}$ against S. aureus and that against E. coli and P. aeruginosa was $25 \mu \mathrm{g} / \mathrm{ml}$. The MIC of Ceftriaxone was the lowest in comparison to MICs of ANLE. The subculture study showed similar results with that of previous experiments in terms of inhibitory effects of CNLP and MICs of ANLE, Ceftriaxone against all of the organisms studied.
\end{abstract}

Key words: Antibacterial effect, crude neem leaf paste (CNLP), Aqueous neeem leaf extract (ANLE), Ceftraxione (antibiotic), Minimum inhibitory concentration (MIC), Staphylococcus aureus, Escherichia coli, Pseudomonas aeruginosa

This article is is licensed under a Creative Commons Attribution-NonCommercial 4.0 International License.

Attribution-NonCommercial (CC BY-NC) license lets others remix, tweak, and build upon work non-commercially, and although the new works must also

acknowledge \& be non-commercial.

\section{INTRODUCTION}

Bangladesh is enriched for many kinds of medicinal plants. The sources of many of the modern medicine are these medicinal plants e.g. the cardiac glycosides, morphine, atropine, castor oil, acetyl salicylic acid (aspirin) Quinine, etc. Gani (2003) stated that approximately $25 \%$ of the people of Bangladesh get modern medical treatment and $75 \%$, remain deprive of it and they depend on depend on traditional medicine to maintain their sound health. Not only in 
Bangladesh, but in many other countries of the world, use of traditional medicine is increasing. In USA the use of herbal medicine is increased 38\% within 1990-1997 and are used as non prescription drugs. In Germany $70 \%$ of the people are fond of herbal medicine in their primary treatment (Gani, 2002). In India herbal medicinal treatment is very much popular. The people of Bangladesh have been using herbal medicine for decades.

Gani (2003) showed that the herbal medicine shares side by side with modern medicine. The budget of health care system in Bangladesh is poor. The traditional medicine are cost effective with low socio-economic condition of poor people in Bangladesh. But all of its constituents are not scientifically evaluated. Dahanukar (2000) reported evidence of immense potential of medicinal plant used in various traditional systems.

Tewari (1992) stated that Neem is a versatile multipurpose tree of tropics. Its pharmacological properties are played the role of "village dispensary" in India. Every part of the tree finding use in one way or other, the Neem is a very important tree due to is medicinal value. Natarajan et al. (2003) had stated in his paper that the medicinal properties of $A$. indica (neem) were studied by several workers. The antipyretic effect, antimalarial effect antitumor effect, antiulcer effect, antidiabetic effect, antifertility effect, effect on central nervous system and cardiovascular effect were some of the studies of the earlier workers. Antimicrobial properties of A. indica were studied by several authors. Roa et al reported the antimicrobial activity of the neem seed oil against a variety of pathogens. The people of Bangladesh use Neem leaves traditionally for different skin diseases, fungal and microbial infections. We planed the present study to find out the antibacterial effect of Neem leaf extract against S. aureus, E. coli, and P. aeruginosa. If we find any antibacterial effects of Neem leaf extract, it will definitely reduce the primary health care cost and random use of antibiotics.

Neem Tree Farms Company (2005) stated about mechanism of action of Neem that while scientists have no yet determined how Neem works. It kills or slows the growth of many disease-causing organisms such as bacteria, virus and fungi. Upadhyay (1998). Investigations on the imunomodulatory properties of Neem with a view to developing neem based products for human use. The results show that neem oil components activate macrophages and stimulate " $\mathrm{T}$ " cell response leading to enhanced cell mediated immunity (CMI). Intrauterine neem treatment (IUNT) may also protect against sexually transmitted diseases (STDs). Kabra and Upadehyay (2000) stated that neem does not kill insects- at least not immediately instead it both repels and disrupts their growth and reproduction. Crude neem extracts absorb the viruses, effectively preventing them from entering unaffected cells. About toxic effects, Neem Tree Farms Company (2005) stated that neem is generally considered to be one of the safest of available medicinal herbs. In neem leaf the following active ingredients are present e.g. Nimbin, Ninbidin, Nimbidol, Gedonin, Sodium nimbinate, Quercetin, Salannin, Azadirachtin etc.

Therefore the study was undertaken to determine the inhibitory effect of CNLP incorporating into solid media against $S$. aureus, E. coli and P. aeruginosa., to investigate the antibacterial effect of ANLE against the organisms by determining its MIC and to assess the MICs of standard antibiotic Ceftriaxone against test organisms and comparison of MICs of ANLE with Ceftriaxone.

\section{Materials AND Methods}

The study was carried out in the Department of Pharmacology \& Therapeutics in collaboration of Department of Microbiology, Mymensingh Medical College, Mymensingh, during the period from July 2004 to June 2005. The present study was designed as a prospective observational one. Recently picked up fresh mature deep green leaves of Jati Neem commonly found in Trishal Upazilla , Mymensingh, Bangladesh. Ceftriaxone: A standard antibiotic of third generation of Cephalosporin (Injection form), 500mg/vial was bought from local market, manufactured by Square Pharmaceuticals LTD., Bangladesh. Test organisms were sStandard reference strains of Staphylococcus aureus, ATCC 25923; Escherichia coli, ATCC 25922 and Pseudomonas aeruginosa, ATCC 27853. The all of the test organisms were collected from the Department of Microbiology, Mymensingh Medical College, Mymensingh. Four separate experiments were done viz., i) Determination of inhibitory effects of crud neem leaf paste (CNLP) by incorporation into nutrient agar media (NA) against Staphylococcus aureus, Escherichia coli, Pseudomonas aeruginosa., ii) Determination of minimum inhibitory concentration (MIC) of aqueous neem leaf extract (ANLE), against test organisms by broth dilution technique, iii) Determination of MIC of standard antibiotic Ceftrixone against test organisms by broth dilution technique as well as making a comparison between MICs of ANLE and Ceftrixone, and iv) Subculture study of materials from effective CNLP, ANLE, and Ceftriaxone in nutrient agar medium for confirmation of respective results of previous experiments I, II, III.

Procedure of Experiment -I: Inhibitory effects of CNLP against test organisms

Technique: By incorporation of CNLP into Nutrient agar media

Preparation of CNLP: Collected Neem leaves were cleaned and washed with plain tap water and dried in shade spreading them on three large trays overnight at normal room temperature in air. The dried Neem leaves were crushed well in mortar under pestle, thus the CNLP was prepared. By weighing with electric balance 500 grams of CNLP were taken for the experiment - I. This CNLP was considered as $100 \%$ crud neem leaf paste. 
Sterilization: Hot air oven: Glass made materials e.g petri dishes, beaker, flat bottomed flasks, measuring cylinder and test tubes, used in the experiment were sterilized by hot air oven, placing them into hot air oven at $160^{\circ} \mathrm{C}$ for one hour. Autoclave: The flask containing the CNLP incorporated into nutrient agar medium used in the experiment - I was sterilized by autoclave.

Preparation of NA media:

$\begin{array}{lc}\text { Composition (Oxoid) } & \text { grams per litre } \\ \text { Lab lemco powder } & 1.0 \\ \text { Yeast extract } & 2.0 \\ \text { Peptone } & 5.0 \\ \text { Sodium chloride } & 5.0 \\ \text { Agar } & 15.0\end{array}$

According to manufacturers instructions $28 \mathrm{gms}$ of dehydrated nutrient agar (Oxoid) were measured by an electric balance and taken in a flask. This powder was to be suspended in 1 litre or 1000ml DW. Now the preparation was brought to boil to dissolve the medium completely. The medium was sterilized by autoclaving under $15 \mathrm{lbs}$ pressure at $121^{\circ} \mathrm{C}$ temperature for 15 minutes.

After sterilization the flask containing the media was allowed to cool in a water bath at $50-55^{\circ} \mathrm{C}$. Then the NA media was dispensed in sterile petri dishes (approximately $10 \mathrm{ml}$ in $90 \mathrm{~mm}$ petri dishes). Prepared media plates may be stored up to one week at $4^{0} \mathrm{C}$ in a refrigerator. Their surfaces should be dried before use.

Preparation of CNLP incorporated into Nutrient agar (NA) media set I:

Set - I: To prepare $0.5 \%$ CNLP incorporated into NA media, 0.5 grams of CNLP was taken in a measuring cylinder. Then NA medium (dissolved) was added with CNLP contained in the measuring flask up to 100ml and this solution was poured in flat bottomed flask and autoclaved for sterilization. After autoclaving the CNLP incorporated into NA media was allowed to cool in water bath around the temperature of $50-55^{\circ} \mathrm{C}$. Then the media was dispensed in previously sterilized petri dishes (approximately $10 \mathrm{ml}$ in each of $90 \mathrm{~mm}$ petri dishes).

Similarly1gm, 2gm, 5gm, 10gm,15gm,20gm,25gm,30gm and 35gms of CNLP were added with dissolved NA media separately to make the volume of each solution up to $100 \mathrm{ml}$ and thus $1 \%, 2 \%, 5 \%, 10 \%, 15 \%, 20 \%, 25 \%, 30 \%$,and $35 \%$ respectively CNLP incorporated NA media were prepared \& were designed as set - I to set - X. The control NA media were also prepared without adding any CNLP with NA media in set -XI (Table 1).

Table 1: Composition of different percentages of CNLP incorporated into NA media

\begin{tabular}{|l|c|c|c|c|}
\hline No. of Sets & $\begin{array}{c}\text { CNLP } \\
\text { gm }\end{array}$ & $\begin{array}{c}\text { Solution containing CNLP in } \\
\text { NA media (dissolved) } \mathrm{ml}\end{array}$ & $\begin{array}{c}\text { Percentage of CNLP } \\
\text { incorporated into NA media \% }\end{array}$ & Test organisms \\
\hline Set - I & 0.5 & 100 & 0.5 & One loop full * \\
\hline Set - II & 1 & 100 & 1 & One loop full \\
\hline Set - III & 2 & 100 & 2 & One loop full \\
\hline Sets - IV & 5 & 100 & 5 & One loop full \\
\hline Set - V & 10 & 100 & 10 & One loop full \\
\hline Set - VI & 15 & 100 & 15 & One loop full \\
\hline Set - VII & 20 & 100 & 20 & One loop full \\
\hline Set -VIII & 25 & 100 & 25 & One loop full \\
\hline Set - IX & 30 & 100 & 30 & One loop full \\
\hline Set - X & 35 & 100 & 35 & One loop full \\
\hline \multicolumn{5}{|c|}{} \\
\hline Set - XI & - & 100 & Control full \\
\hline
\end{tabular}

*One loop full $=20 \mu 1$

Preparation of inoculums or bacterial suspension: For each of the test organisms the separate inoculums were prepared in the following ways. 3-5 similar colonies from 18-24 hours old agar plates were picked up with sterile wire loop and mixed with sterile saline. The turbidity was adjusted with 0.05 McFarland standards by adding saline or colony to the suspension. The turbidity of 0.05 (one half of) McFarland standard corresponds to $1.5 \times 10^{8}$ organisms $/ \mathrm{ml}$

Inoculation: A sterile cotton swab was dipped in the bacterial suspension and pressed against the wall of the test tube to remove excess fluid. The entire surface of the CNLP incorporated NA media was inoculated by streaking with the swab. It was repeated more than two times by rotating the plates approximately at $60^{\circ}$ angle. Finally the rim of the plate was inoculated. Bacterial suspensions were also inoculated in control plates. 
The plates were inverted and there strength were marked with black marker pen and placed in the incubator at $37^{\circ} \mathrm{C}$ for 18-24 hours. After incubation at $37^{\circ} \mathrm{C}$ the growth of test organisms were examined by naked eyes. Control plates without incorporated CNLP were also examined for growth of test organisms (Table - II)

Procedure of Experiment - II: Determination of MICs of ANLE against Staphylococcus aureus, Escherichia coli and Pseudomonas aeruginos by broth dilution.

Syringe filter: ANLE $(35.7 \mathrm{mg} / \mathrm{ml})$ was sterilized by membrane filtration using a $20 \mathrm{ml}$ syringe filter. Prior to filtration, the membrane filter along with the apparatus was autoclaved. ANLE was poured in the syringe and pressure from the back was applied by piston to quicken filtration in a flat bottomed flask \& by hot air oven \& autoclave as before.

Preparation of ANLE: Six hundred grams of Neem leaves after cleaning, washing and drying were crushed well in mortar under pestle. Two hundred and eighty (280)gms of crushed Neem leaves were measured in an electric balance and was taken in a beaker and dissolved in $560 \mathrm{ml}$ of sterile DW and mixed well by stirring and placing the beaker on the laboratory rotator for one hour. Then this preparation was kept at $4^{0} \mathrm{c}$ for 24 hours. Then the preparation was filtered by using a funnel with Whatman filter paper no. - I and collected in a measuring flask. The weight of waste neem leaves after filtration was again measured by the electric balance and was weighed about $260 \mathrm{gms}$. So, $(280 \mathrm{gm}-260 \mathrm{gm}) 20 \mathrm{gms}$ neem leaf extract was found in $560 \mathrm{ml}$ of DW. With ANLE of concentrations $35.7 \mathrm{mg} / \mathrm{ml}$ thus prepared, $2 \mathrm{ml}$ of ethanol was mixed (as preservative) to prevent fungal growth. This ANLE was preserved at $4^{0} \mathrm{C}$ to determine its MIC against test organisms (Calculations were attached in this chapter in page no.34). ANLE was sterilized by membrane filter before use (Mrs. Monowara Begum, Director, Plant Extraction Section BCSIR, Dhaka, Bangladesh. Personal communication)

Preparation of Nutrient broth medium

Composition (Oxoid) grams per litre

Lab lemco powder $\quad 1.0$

Yeast extract $\quad 2.0$

Peptone $\quad 5.0$

Sodium chloride $\quad 5.0$

Method of preparation:According to manufacturers instructions $13 \mathrm{gm}$ of dehydrated nutrient broth medium was measured by an electric balance and taken in a flask. This was then suspended in 1 litre or 1000ml DW. Now the preparation was brought to boil to dissolve the medium completely. The medium was sterilized by autoclaving under $15 \mathrm{lbs}$ pressure at $121^{\circ} \mathrm{C}$ temperature for 15 minutes. After sterilization the flask containing the media was allowed to cool at room temperature. Then the media was dispensed in measured amounts in $15 \mathrm{ml}$ test tubes for the use in different experiments.

Preparations of stock ANLE:

Calculations:

Crushed neem leaves in gms - waste neem leaves after filtration in gms = NLE in gms

$280 \mathrm{gm}-260 \mathrm{gm}=20 \mathrm{gm}$ of neem leaf extract.

$560 \mathrm{ml}$ of DW contained $20 \mathrm{gm}$ of NLE

$1 \mathrm{ml} \mathrm{DW}$ contained $0.0357 \mathrm{gm}=35.7 \mathrm{mg}$ of NLE

$10 \mathrm{ml}$ of DW contained $357 \mathrm{mg}$ of NLE

$10 \mathrm{ml}$ of sterile ANLE of concentration $35.7 \mathrm{mg} / \mathrm{ml}$ was mixed with $90 \mathrm{ml}$ of sterile DW to make $100 \mathrm{ml}$ of stock solution in a sterile beaker.

Now, $100 \mathrm{ml}$ of the solution contained $357 \mathrm{mg}$ of NLE

$1 \mathrm{ml}$ of the solution contained $3.57 \mathrm{mg}$ of NLE

Now, $1 \mathrm{ml}$ of stock ANLE solution contained $3.57 \mathrm{mg} / \mathrm{ml} \mathrm{NLE}$.

This solution was used as stock solution in the measurement of minimum inhibitory concentration (MIC) of the aqueous neem leaf extract (ANLE). From this stock ANLE different dilutions and concentrations were made.

Method of preparations of different dilutions and concentrations of stock ANLE:

Set - I of 1:1.25 dilution of stock ANLE was made by mixing $8 \mathrm{ml}$ of stock ANLE by a measuring pipette with $2 \mathrm{ml}$ of nutrient broth medium $(10 \mathrm{ml})$ in a $(15 \mathrm{ml})$ test tubes. Now the concentration of this dilution was $2856 \mu \mathrm{g} / \mathrm{ml}$.

$1 \mathrm{ml}$ of stock ANLE contained $3.57 \mathrm{mg}$ of NLE

So, $8 \mathrm{ml}$ of stock ANLE contained $3.57 \times 8 \mathrm{mg}=28.56 \mathrm{mg} \times 1000=28560 \mu \mathrm{g} / \mathrm{ml}$ of NLE . 
Now $10 \mathrm{ml}$ of the preparations contained $28560 \mu \mathrm{g} / \mathrm{ml}$ of NLE

$1 \mathrm{ml}$ of the preparations contained $2856 \mu \mathrm{g} / \mathrm{ml}$ of NLE

So, Set - I of 1:1.25 dilution of stock ANLE contained $2856 \mu \mathrm{g} / \mathrm{ml}$ of NLE

Similarly, Set - II. of 1:2 dilution of stock ANLE solution was made by mixing $5 \mathrm{ml}$ of stock ANLE with $5 \mathrm{ml}$ of nutrient broth medium in test tubes. Now the concentration of this dilutions was $1785 \mu \mathrm{gm} / \mathrm{ml}$.

Then Sets - III, IV,V,VI,VII,VIII and IX of 1:2.5dil., 1:5dil. 1:10 dil., 1:20dil., 1:40dil., 1:80dil., and 1:160 dilutions respectively of stock ANLE were made in different test tubes by mixing of measured amount of stock ANLE with measured amount of nutrient broth medium. The concentrations of these sets were $1428 \mu \mathrm{g} / \mathrm{ml}, 714 \mu \mathrm{g} / \mathrm{ml}$, $357 \mu \mathrm{g} / \mathrm{ml}, 178.5 \mu \mathrm{g} / \mathrm{ml}, 89.25 \mu \mathrm{g} / \mathrm{ml}, 44.62 \mu \mathrm{g} / \mathrm{ml}$ and $22.31 \mu \mathrm{g} / \mathrm{ml}$ respectively (Table 6.2). Three types of controls were also made. Controls -1 were made each with $10 \mathrm{ml}$ of stock ANLE (to be inoculated with bacterial suspension) in test tubes. Controls 2 - were made with $10 \mathrm{ml}$ of nutrient broth medium (to be inoculated with bacterial suspension) in test tubes. Controls -3 were made with $10 \mathrm{ml}$ of nutrient broth medium (did not inoculated with bacterial suspension) in test tubes (Table 2).

Table 2: Composition of different dilutions, concentrations of ANLE and the controls

\begin{tabular}{|l|c|c|c|c|c|c|}
\hline No. of sets & $\begin{array}{c}\text { Dilutions of } \\
\text { stock ANLE }\end{array}$ & $\begin{array}{c}\text { ANLE } \\
\mathrm{ml}\end{array}$ & $\begin{array}{c}\text { Nutrient broth } \\
\text { Medium } \mathrm{ml}\end{array}$ & $\begin{array}{c}\text { Total } \\
\mathrm{ml}\end{array}$ & $\begin{array}{c}\text { Concentration of } \\
\text { ANLE } \mu \mathrm{g} / \mathrm{ml}\end{array}$ & $\begin{array}{c}\text { Test } \\
\text { Organisms } \mu \mathrm{l}\end{array}$ \\
\hline Set - I & $1: 1.25$ & 8 & 2 & 10 & 2856 & 20 \\
\hline Set - II & $1: 2$. & 5 & 5 & 10 & 1785 & 20 \\
\hline Set - III & $1: 2.5$ & 4 & 6 & 10 & 1428 & 20 \\
\hline Set - IV & $1: 5$ & 2 & 8 & 10 & 714 & 20 \\
\hline Set - V & $1: 10$ & 1 & 9 & 10 & 357 & 20 \\
\hline Set - VI & $1: 20$ & 0.5 & 9.5 & 10 & 178.5 & 20 \\
\hline Set - VII & $1: 40$ & 0.25 & 9.75 & 10 & 89.25 & 20 \\
\hline Set - VIII & $1: 80$ & 0.125 & 9.875 & 10 & 44.62 & 20 \\
\hline Set - IX & $1: 160$ & 0.625 & 9.375 & 10 & 22.31 & 20 \\
\hline \multicolumn{7}{|l|}{ Controls } \\
\hline Set - X & Control:1 & 10 & - & 10 & 3570 & 20 \\
\hline Set - XI & Control:2 & - & 10 & 10 & - & 20 \\
\hline Set - XII & Control:3 & - & 10 & 10 & - & - \\
\hline
\end{tabular}

With each $10 \mathrm{ml}$ preparation except control 3 (set XII) $20 \mu \mathrm{l}$ bacterial suspensions were added after matching its opacity with that of McFarland Standard.

McFarland Standard Tube No. I

Composition and preparation: It is a turbidity standard. $1 \%(\mathrm{~V} / \mathrm{V})$ solution of chemically pure $(0.36 \mathrm{~N})$ Sulphuric acid and $1.175 \%(\mathrm{~W} / \mathrm{V})$ solution of chemically pure $(0.048 \mathrm{M})$ barium chloride was prepared in nutrient broth in two separate sterile flasks. Then $9.9 \mathrm{ml}$ of sulphuric acid and $0.1 \mathrm{ml}$ of barium chloride were added to the clean screw capped test tube and sealed. The barium sulphate suspension corresponds approximately to McFarland standard tube No. I with corresponding cell density of $3 \times 10^{8}$ organisms $/ \mathrm{ml}$.

To make the turbidity standard of cell density to one half of the McFarland standard tube No. 1 which corresponds to cell density of $1.5 \times 10^{8}$ organisms $/ \mathrm{ml}$ for determination of antibiotic sensitivity by kirby -Baur inoculated techninique. Barium chloride $\left(\mathrm{Bacl}_{2}, 2 \mathrm{H}_{2} 0\right) 0.5 \mathrm{ml}$ of $1.75 \%(\mathrm{~W} / \mathrm{V})$ was added to $99.5 \mathrm{ml}$ of $\mathrm{I} \%(\mathrm{~V} / \mathrm{V})$ sulphuric acid $(0.36 \mathrm{~N})$, mixed well and $5-10 \mathrm{ml}$ was distributed in sterile screw capped test tubes and sealed. Preparation of inoculums was same as previously mentioned in experiment $\mathrm{I}$.

Inoculation of bacterial suspension to different dilutions and concentrations of stock ANLE with nutrient broth media in test tubes: After matching the turbidity of bacterial suspension with the McFarland standard $20 \mu \mathrm{l}$ or one drop $(0.02 \mathrm{ml})$ of bacterial suspension of Staph. aureus, Esch. coli and Ps. aeruginosa were separately added with preparations of each dilutions and concentrations of stock ANLE in separate test tubes by sterilized micropipettes. These inoculums were also added with the controls (1 and 2 ) except Controls-3. The test tubes were marked set wise with black marker pen. Then these preparations were placed in the incubator at $37^{\circ} \mathrm{C}$ for $18-24$ hours.

Examination of growth of test organisms in different concentrations of ANLE preparations: After $18-24$ hours of incubation at $37^{\circ} \mathrm{C}$, the growth of test organisms in each preparations of ANLE were examined and compared against that of controls by matching their turbidity. The clear preparations were considered as no growth of bacteria and turbid 
ones, as growth of bacteria. The MIC was reported as lowest concentration of ANLE required to prevent the visible growth of test organisms (Table 3).

Procedure of experiment-III: Determination of MIC of Ceftriaxone against test organisms by broth dilution. All the materials were the same as experiment II except stock Ceftriaxone solution and sterile DW instead of ANLE. Sterilization was as experiment II.

Preparation of nutrient broth medium: After sterilization by autoclave nutrient broth media was allowed to cool below $40^{\circ} \mathrm{C}$ to be poured in the test tubes in measured amount to mix with the measured amount of stock solution of Ceftriaxone to prepare its different dilutions and concentrations. Then for stock solution of Ceftriaxone five hundred (500) $\mathrm{mg}$ of Cefraxone powder in the vial was mixed well with $5 \mathrm{ml}$ of supplied sterile DW by supplied syringe. The prepared Ceftriaxone injection had the concentration of 500mg in $5 \mathrm{ml}$. So, 100mg of Ceftriaxone contained in $1 \mathrm{ml}$ of sterile DW. Then $1 \mathrm{ml}$ of solution was mixed with $9 \mathrm{ml}$ of sterile DW. This 1:10 dilution of stock Ceftriaxone solution had the concentration was $10 \mathrm{mg} / \mathrm{ml} .1 \mathrm{ml}$ of this preparation was mixed with $9 \mathrm{ml}$ of sterile DW. The concentration of prepared solution of Ceftriaxone was $1 \mathrm{mg} / \mathrm{ml}$, which was used as its stock solution for the determination of its MIC.

\section{Calculations:}

Ceftriaxone $500 \mathrm{mg}$ in $5 \mathrm{ml}$ $500 \mathrm{mg}$ Ceftriaxone in $5 \mathrm{ml}$. $100 \mathrm{mg}$ Ceftriaxone in $1 \mathrm{ml}$. $\downarrow 1$ : 10 dilutions.

Concentration: $10 \mathrm{mg} / \mathrm{ml}$

$$
\downarrow 1: 10 \text { dilutions }
$$

Concentration: $1 \mathrm{mg} / \mathrm{ml}$

$1 \mathrm{mg} / \mathrm{ml}$ preparation was used as the stock solution of Ceftriaxone for the determination its MIC by broth dilution technique. Different dilutions of this stock Ceftriaxone solution were made to have different concentrations.

Step - IV: Method of preparation of different dilutions and concentrations of stock Ceftriaxone solution:

Set - I. of 1:10 dilution of stock Ceftriaxone solution was made by adding $1 \mathrm{ml}$ of Ceftriaxone stock solution with $9 \mathrm{ml}$ of nutrient broth medium. The concentration of Ceftriaxone in this dilution was $100 \mu \mathrm{g} / \mathrm{ml}$.

\section{Calculations: Set I:}

1:10 dil. of stock Cefriaxone solution contained $1 \mathrm{ml}$ of stock Ceftriaxone solution mixed with $9 \mathrm{ml}$ of NB medium $(10 \mathrm{ml})$.

$1 \mathrm{ml}$ of stock Ceftriaxone solution contained $1 \mathrm{mg}$ or $1000 \mu \mathrm{g}$ of Ceftriaxone .

Then $10 \mathrm{ml}$ of set I preparation contained $1000 \mu \mathrm{g}$ of Ceftriaxone .

Then $1 \mathrm{ml}$ of set I preparation contained $100 \mu \mathrm{g}$ of Ceftriaxone / $\mathrm{ml}$

Set-II of 1:20 dilution of stock Ceftriaxone solution was made by adding $0.5 \mathrm{ml}$ of Ceftriaxone stock solution with $9.5 \mathrm{ml}$ of nutrient broth medium. The concentration of Ceftriaxone in this dilution was $50 \mu \mathrm{g} / \mathrm{ml}$.

\section{Calculations: Set II:}

1:20 dil. of stock Cefriaxone solution contained $0.5 \mathrm{ml}$ of stock Ceftriaxone solution mixed with $9.5 \mathrm{ml}$ of NB medium $(10 \mathrm{ml})$.

$1 \mathrm{ml}$ of stock Ceftriaxone solution contained $1 \mathrm{mg}$ or $1000 \mu \mathrm{g}$ of Ceftriaxone.

$0.5 \mathrm{ml}$ of stock Ceftriaxone solution contained $500 \mu \mathrm{g}$ of Ceftriaxone .

Then $10 \mathrm{ml}$ of set II preparation contained $500 \mu \mathrm{g}$ of Ceftriaxone .

Then $1 \mathrm{ml}$ of set I preparation contained $50 \mu \mathrm{g}$ of Ceftriaxone $/ \mathrm{ml}$

Similarly, Set - III, IV,V and VI of 1:40dil.,1:100 dil.,1:200 dil. and 1:1000 dilutions respectively were made by adding measured amount of Ceftriaxone stock solution with measured amount of broth medium. The concentrations of Ceftriaxone in these dilutions were $25 \mu \mathrm{g} / \mathrm{ml}, 10 \mu \mathrm{g} / \mathrm{ml}, 5 \mu \mathrm{g} / \mathrm{ml}$ and $1 \mu \mathrm{g} / \mathrm{ml}$, respectively (Table 3). Controls 1- were made with $10 \mathrm{ml}$ of nutrient broth medium (to be inoculated with bacterial suspension) in test tubes. Controls- 2 was made with $10 \mathrm{ml}$ of nutrient broth medium (no to be inoculated with bacterial suspension) in test tubes (Table 3). 
Table 3: Composition of different dilutions, concentrations of Ceftriaxone and the controls

\begin{tabular}{|c|c|c|c|c|c|c|}
\hline $\begin{array}{l}\text { No. of } \\
\text { sets }\end{array}$ & $\begin{array}{c}\text { Dilutions of stock } \\
\text { Ceftriaxone }\end{array}$ & $\begin{array}{l}\text { Ceftriaxone } \\
\mathrm{ml}\end{array}$ & $\begin{array}{l}\text { Nutrient broth } \\
\text { Medium ml }\end{array}$ & $\begin{array}{c}\text { Total } \\
\mathrm{ml}\end{array}$ & $\begin{array}{c}\text { Concentration of } \\
\text { Ceftriaxone } \mu \mathrm{g} / \mathrm{ml}\end{array}$ & $\begin{array}{c}\text { Test } \\
\text { organisms } \mu \mathrm{l}\end{array}$ \\
\hline Set - I & $1: 10$ & 1 & 9 & 10 & 100 & 20 \\
\hline Set - II & $1: 20$ & 0.5 & 9.5 & 10 & 50 & 20 \\
\hline Set - III & $1: 40$ & 0.25 & 9.75 & 10 & 25 & 20 \\
\hline Set - IV & 1: 100 & 0.1 & 9.9 & 10 & 10 & 20 \\
\hline Set $-V$ & $1: 200$ & 0.05 & 9.95 & 10 & 5 & 20 \\
\hline Set - VI & $1: 1000$ & 0.01 & 9.99 & 10 & 1 & 20 \\
\hline \multicolumn{7}{|c|}{ Controls } \\
\hline Set - VII & Control : 1 & - & 10 & 10 & - & 20 \\
\hline Set - VIII & Control :2 & - & 10 & 10 & - & - \\
\hline
\end{tabular}

With each 10ml preparation except control 2 (set VIII) $20 \mu \mathrm{l}$ bacterial suspensions were added after matching its opacity with that of McFarland Standard.

Preparation of inoculums was same as in experiment-II.

Inoculation of bacterial suspension to different dilutions and concentrations of stock Ceftriaxone in test tubes: Same as previous experiment II. Incubation was same as previous experiments to II.

Examinations of test organisms in different dilutions and concentrations of Ceftriaxone: After 18-24 hours of incubation at $37^{\circ} \mathrm{C}$, the growth of test organisms in each preparations of Ceftriaxone were examined and compared against that of controls by matching their turbidity. The clear preparations were considered as no growth of bacteria and turbid ones, as growth of bacteria. The MIC was reported as lowest concentration of Ceftriaxone required to prevent the visible growth of test organisms.

Experiment - IV: Subculture study of materials from effective CNLP, ANLE, and Ceftriaxone preparations for confirmation of respective results of experiments I, II \& III: Subculture of CNLP materials in NA media: The materials from last two sets of growth and all sets of no growth of CNLP incorporated into NA media were subcultured in the pure NA (solid) media plates (without any incorporation of CNLP). After 18-24 hours of incubation at $37^{\circ} \mathrm{C}$, the growth of test organisms were examined.

Subculture of materials from effective dilutions of ANLE, and Ceftriaxone in NA media: The materials from last two sets of growth and all sets of no growth of $S$. aureus, E. coli and P. aeruginosa from dilutions of ANLE, and Ceftriaxone preparations were sub cultured in the pure NA (solid) media plates (without any NLE and antibiotic mixed with the media). After $18-24$ hours of incubation at $37^{\circ} \mathrm{C}$, the growth of test organisms were examined.

\section{RESULTS AND Discussions}

The MIC or Minimum Inhibitory Concentration was the smallest concentration of a drug or an antibiotic in the series that prevents the development of visible growth of the test organisms. There was no inhibition of growth of Staph. aureus, Esch. coli and Ps. aeruginosa at .5\%, 1\% and 2\% crude neem (A. indica) leaf paste incorporated solid media (Figure 1). The growth of staph. aureus was started to be inhibited from $5 \%$ and complete inhibition of growth occurred at 15\%and above of CNLP incorporated into NA media. There was no inhibition of growth of Esch. coli from $0.5 \%$ to $5 \%$ CNLP incorporated medium. The growth of Esch. coli started to be inhibited from $10 \%$ CNLP incorporated media and their growths were completely inhibited at $20 \%$ and above. The growth of Ps. aeruginosa started to be inhibited from $15 \%$ and completely inhibited at $25 \%$ and above of CNLP incorporated into NA media. Controls without any CNLP show huge growth of all of the test organisms. Crude neem $(A$. indica) leaf paste (CNLP) incorporated into nutrient agar media had a definite inhibitory effects against growth of Staph. aureus, Esch. coli and Ps. aeruginosa at 15\% (Set VI), 20\%(Set VII), 25\%(Set VIII) respectively. 
Table 4: Inhibitory effect of CNLP incorporated into Nutrient agar medium against growth of S. aureous, E. coli and P. aeruginosa.

\begin{tabular}{|c|c|c|c|c|}
\hline \multirow{2}{*}{$\begin{array}{l}\text { N0. of } \\
\text { Sets }\end{array}$} & \multirow{2}{*}{$\begin{array}{l}\text { Percentages of CNLP } \\
\text { incorporated into NA } \\
\text { media }\end{array}$} & \multicolumn{3}{|c|}{ Observations } \\
\hline & & $\begin{array}{l}\text { Staphylococcus } \\
\text { aureous }\end{array}$ & Escherichia coli & $\begin{array}{l}\text { Pseudomonus } \\
\text { aeruginosa }\end{array}$ \\
\hline Set - I & $0.5 \%$ & Growth not inhibited & Growth not inhibited & Growth not inhibited \\
\hline Set - II & $1 \%$ & Growth not inhibited & Growth not inhibited & Growth not inhibited \\
\hline Set - III & $2 \%$ & Growth not inhibited & Growth not inhibited & Growth not inhibited \\
\hline Set - IV & $5 \%$ & Medium growth & Growth not inhibited & Growth not inhibited \\
\hline Set $-\mathrm{V}$ & $10 \%$ & $\begin{array}{l}\text { Just visible (scanty) } \\
\text { growth }\end{array}$ & Medium growth & Growth not inhibited \\
\hline Set - VI & $15 \% *$ & $\begin{array}{l}\text { Growth completely } \\
\text { inhibited * }\end{array}$ & $\begin{array}{l}\text { Just visible (scanty) } \\
\text { growth }\end{array}$ & Medium growth \\
\hline Set - VII & $20 \% *$ & $\begin{array}{l}\text { Growth completely } \\
\text { inhibited }\end{array}$ & $\begin{array}{l}\text { Growth completely } \\
\text { inhibited * }\end{array}$ & $\begin{array}{l}\text { Just visible (scanty) } \\
\text { growth }\end{array}$ \\
\hline $\begin{array}{l}\text { Set - } \\
\text { VIII }\end{array}$ & $25 \%$ * & $\begin{array}{l}\text { Growth completely } \\
\text { inhibited }\end{array}$ & $\begin{array}{l}\text { Growth completely } \\
\text { inhibited }\end{array}$ & Growth completely inhibited * \\
\hline Set - IX & $30 \%$ & - & $\begin{array}{l}\text { Growth completely } \\
\text { inhibited }\end{array}$ & Growth completely inhibited \\
\hline Set $-X$ & $35 \%$ & - & - & Growth completely inhibited \\
\hline \multicolumn{5}{|c|}{ Control } \\
\hline Set - XI & $\begin{array}{c}\text { Media without any } \\
\text { CNLP }\end{array}$ & Huge growth & Huge growth & Huge growth \\
\hline
\end{tabular}

* indicates the lowest percentages of CNLP incorporated into nutrient agar media for complete inhibition of growth of test organisms.

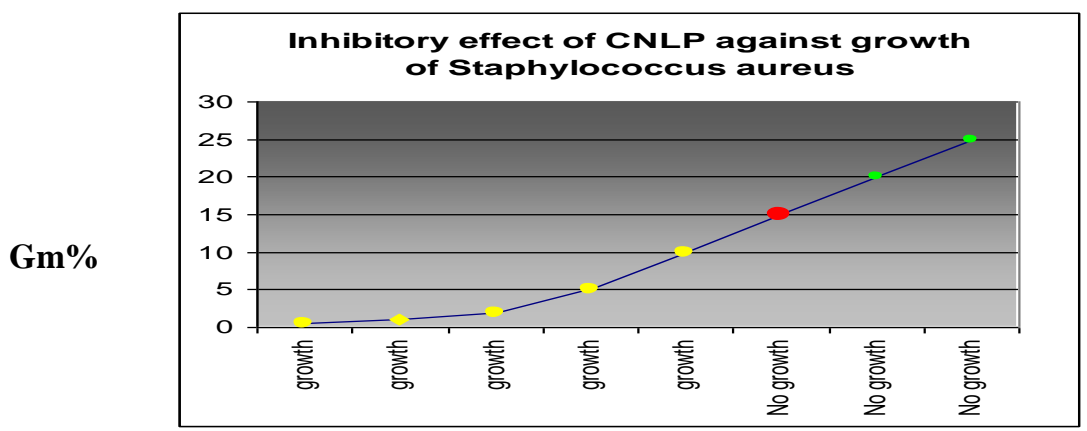

Fig 1: The line graph representing by yellow markings the percentages of CNLP $(0.5 \%-10 \%)$ of visible growth and by red and green markings, $(15 \%-25 \%)$ of no growth of $S$. aureus. The red marking indicates the lowest percentage of CNLP (15\%) showing no growth or complete inhibition of growth of S. aureus.

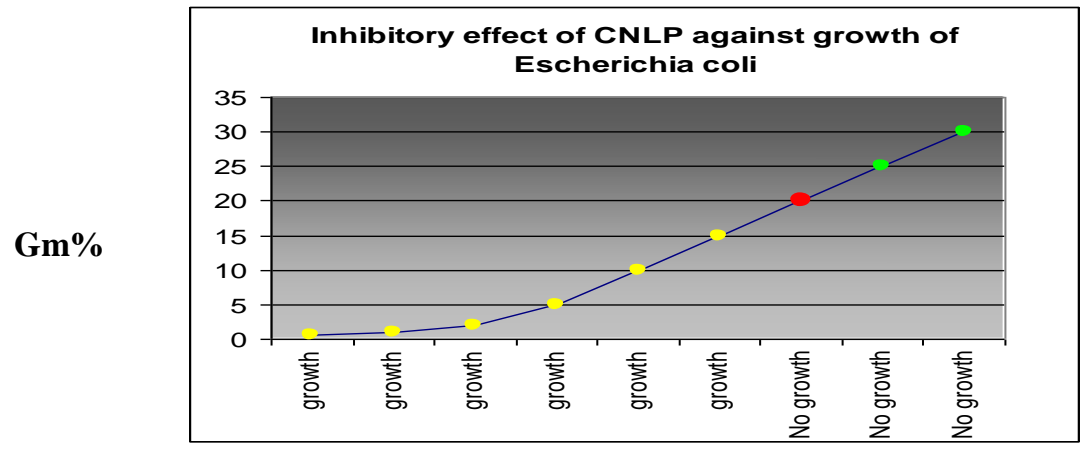

Fig 2: The line graph representing by yellow markings the percentages of CNLP( $0.5 \%-15 \%)$ of visible growth and by red and green markings, $(20 \%-30 \%)$ of no growth of Esch .coli. The red marking indicates the lowest percentage of CNLP $(20 \%)$ showing no growth or complete inhibition of growth of Esch .coli. 


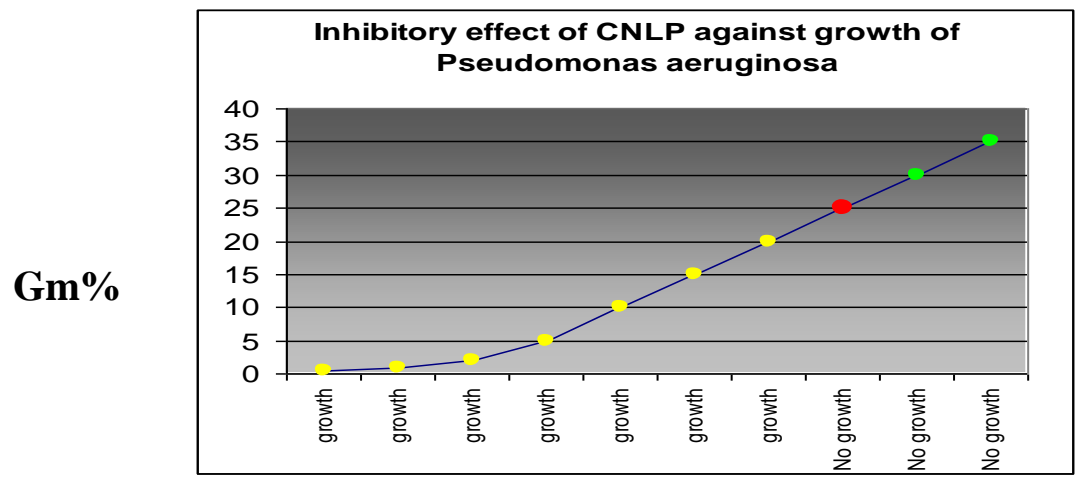

Fig 3: The line graph representing by yellow markings the percentages of $\operatorname{CNLP}(0.5 \%-20 \%)$ of visible growth and by red and green markings, $(25 \%-35 \%)$ of no growth of Ps. aeruginosa.. The red marking indicates the lowest percentage of CNLP $(25 \%)$ showing no growth or complete inhibition of growth of Ps. aeruginosa.

The full part of neem leaves were used in CNLP incorporated in NA media. The CNLP incorporated into nutrient agar (NA) media of different percentages e.g. $0.5 \%, 1 \%, 2 \%, 5 \%, 10 \%, 15 \%, 20 \%, 25 \%, 30 \%$ and $35 \%$ of were made. $S$. aureus was inoculated in $0.5 \%$ to $25 \%$; E coli, in $0.5 \%$ to $30 \%$ and $P$. aeruginosa in $0.5 \%$ to $35 \%$ of CNLP incorpoted into NA media. The overnight incubated culture plates showed visible growth of Staph. aureus in $0.5 \%$ to $10 \%$ and that failed to grow in $15 \%$ to $25 \%$. The lowest percentage at which $S$. aureus failed to grow was $15 \%$ CNLP incorporated into NA media. The inoculation of $E$. coli showed visible growth in $0.5 \%$ to $15 \%$ and no growth in $20 \%-$ $30 \%$. The $20 \%$ CNLP incorporated into NA media was the lowest percentage showing inhibitory effects against $E$. coli. The inoculation of $P$. aeruginosa showed its visible growth in $0.5 \%$ to $20 \%$ and its no growth from $25 \%$ to $35 \%$. The lowest percentage with no growth of $P$. aeruginosa was $25 \%$ CNLP incorporated into NA media. Churasia and Jain (1978) investigated inhibitory effects of essential oils of $A$. indica (by disk diffusion method) found that $A$. indica have inhibitory activity against all of the eleven test organisms including Staph. aureus and Esch. coli. He also stated that similar inhibitory effects were reported by Jain and Agrawal (1976) who found that the leaf extract of "Azadirachta indica" possessed an anti-microbial property against the (-) strain of "Nannizzia gypsea" and Fries (1937) has reported the essential oils contain sterols and terpenes and these components are the main active ingredients responsible for their anti-microbial activity.

The MIC of ANLE against S. aureus was $714 \mu \mathrm{g} / \mathrm{ml}$ of $1: 5$ dilutions of Set IV and that against Esch. coli and Ps. aeruginosa were similar and was $1428 \mu \mathrm{g} / \mathrm{ml}$ in 1:2.5 dilutions of Set III Figure 2. Visible growth of S. aureus were observed in 1:10 dil. to 1:160 dilutions and the organisms failed to grow in 1:5 dil. to 1:1.25dilutions. So the minimum inhibitory concentration (MIC) of ANLE against of Staphy. aureus was in 1:5 dilution of concentration 714 $\mu \mathrm{g} / \mathrm{ml}$. The visible growth of Esch. coli and Ps. aeruginosa were shown in 1:5 dil. to 1:160 dilutions. When their growth were not visible in 1:2.5 dil to 1:1.25 dilutions. So the MIC of ANLE against Esch. coli and Ps. aeruginosa was the similar and found in 1:2.5 dilution of concentration $1428 \mu \mathrm{g} / \mathrm{ml}$ (Figure 2). The test organisms failed to grow in controls - 1: containing pure stock solution of ANLE with bacterial inoculations. Controls - 2: containing nutrient broth medium with inoculation of bacteria showed their visible growth and Controls - 3: containing nutrient broth medium without any bacterial inoculation showing no visible growth of test organisms (Table 5).

\section{Calculations:}

Thus Set - III of 1: 2.5 dilution of stock ANLE being composed of 4ml stock ANLE mixing with $6 \mathrm{ml}$ of nutrient broth medium $(10 \mathrm{ml})$.

$1 \mathrm{ml}$ stock ANLE contained $3.57 \mathrm{mg}$ of NLE

$4 \mathrm{ml}$ stock ANLE contained $3.57 \mathrm{mg} \times 4=14.28 \mathrm{mg}$ of NLE

Now, $10 \mathrm{ml}$ of preparation contained $14.28 \mathrm{mg}$ of NLE

$1 \mathrm{ml}$ of preparation contained $1.428 \mathrm{mg}$ of NLE $\times 1000=1428 \mu \mathrm{g} / \mathrm{ml}$.

So, the concentration of 1:2.5 dilutions of stock ANLE was $1428 \mu \mathrm{g} / \mathrm{ml}$.

Set IV of 1:5 dilution of stock ANLE was composed of $2 \mathrm{ml}$ of stock ANLE diluted with $8 \mathrm{ml}$ of nutrient broth medium $(10 \mathrm{ml})$

$1 \mathrm{ml}$ stock ANLE contained $3.57 \mathrm{mg}$ of NLE

$2 \mathrm{ml}$ stock ANLE contained $3.57 \mathrm{mg} \times 2 \mathrm{mg}$ of NLE $=7.14 \mathrm{mg}$ of NLE

Now, $10 \mathrm{ml}$ of preparation contained $7.14 \mathrm{mg}$ of NLE

$1 \mathrm{ml}$ of preparation contained $0.714 \mathrm{mg} \times 1000=714 \mu \mathrm{g} / \mathrm{ml}$ of NLE

So, the concentration of 1:5 dilutions of stock ANLE was $714 \mu \mathrm{g} / \mathrm{ml}$. 
Table 5: MIC of ANLE against of S. aureous, E. coli and P. aeruginosa

\begin{tabular}{|c|c|c|c|c|c|}
\hline \multirow[t]{2}{*}{ No. of Sets } & \multirow{2}{*}{$\begin{array}{l}\text { Dilutions of } \\
\text { stock ANLE }\end{array}$} & \multirow{2}{*}{$\begin{array}{c}\text { Concentrations } \\
\mu \mathrm{gm} / \mathrm{ml}\end{array}$} & \multicolumn{3}{|c|}{ Observations } \\
\hline & & & Staph.aureous & Esch. coli & Ps. Aeruginosa \\
\hline Set -I & $1: 1.25$ & 2856 & No growth & No growth & No growth \\
\hline Set - II & $1: 2$ & 1785 & No growth & No growth & No growth \\
\hline Set - III & $1: 2.5$ & 1428 * & No growth & No growth & No growth \\
\hline Set - IV & $1: 5$ & $714^{*}$ & No growth & growth & growth \\
\hline Set $-\mathrm{V}$ & $1: 10$ & 357 & Growth & Growth & Growth \\
\hline Set - VI & $1: 20$ & 178.5 & Growth & Growth & Growth \\
\hline Set - VII & $1: 40$ & 89.25 & Growth & Growth & Growth \\
\hline Set - VIII & $1: 80$ & 44.62 & Growth & Growth & Growth \\
\hline Set - IX & $1: 160$ & 22.31 & Growth & Growth & Growth \\
\hline \multicolumn{6}{|c|}{ Controls } \\
\hline Set $-X$ & Control - 1 & Pure stock ANLE + Bacterial inoculation & No growth & No growth & No growth \\
\hline Set $-\mathrm{XI}$ & Control 2: & NB Media+ Bacterial inoculation & Growth & Growth & Growth \\
\hline Set - XIII & Control 3: & NB Media+ No bacterial inoculation & No growth & No growth & No growth \\
\hline
\end{tabular}

* $=$ MIC of Aqueous neem leaf extract

ANLE was fully a water soluble extract. The water soluble ingredients of neem leaves were present in ANLE. Using broth dilution technique, the stock solution of ANLE of conc. $3.57 \mathrm{mg} / \mathrm{ml}$ was diluted to 1:1.25 dil, 1:2 dil., 1:2.5 dil., 1:5 dil., 1:10 dil., 1:20 dil., 1:40 dil., 1:80 dil. and 1:160 dilutions by mixing different amounts of stock ANLE with different amounts of nutrient broth (NB) medium to prepare different concentrations of solutions such as $2865 \mu \mathrm{g} / \mathrm{ml}, 1785 \mu \mathrm{g} / \mathrm{ml}, 1428 \mu \mathrm{g}$ $/ \mathrm{ml}, 714 \mu \mathrm{g} / \mathrm{ml}, 357 \mu \mathrm{g} / \mathrm{ml}, 178.5 \mu \mathrm{g} / \mathrm{ml}, 89.25 \mu \mathrm{g} / \mathrm{ml}, 44.62 \mu \mathrm{g} / \mathrm{ml}$ and $22.31 \mu \mathrm{g} / \mathrm{ml}$ respectively. The inoculation of Staph. aureus showed visible growth of Staph. aureus in 1:10 dil. to 1:160 dil. and that failed to grow in 1:5 dil. to 1:1.25 dilutions. The minimum inhibitory concentration (MIC) of ANLE against Staph. aureus was in 1:5 dilution of concentration $714 \mu \mathrm{g} / \mathrm{ml}$. In case of Esch. coli and Ps. aeruginosa visible growth was found in 1:5 dilution to 1:160 dilutions and no visible growth, in 1:2.5 to 1:1.25 dilutions of ANLE. So, the MIC of ANLE against both of the organisms was in 1:2.5 dilution of concentration 1428 $\mu \mathrm{g} / \mathrm{ml}$. Rao et al. (1986) stated that two hundred clinical isolates of bacteria subjected to antibacterial effects of Neem oil showed $92 \%$ susceptibility, the minimum inhibitory concentration (MIC) varying between $1 / 4 \mathrm{t} 01 / 64$ dil.

The MIC of Neem oil for Ps. aeruginosa, ranged from ${ }^{1} / 8$ dil. for $50 \%$ of strains to $1 / 32$ dil for $40 \%$ of strains. For Staph. aureus it varied between $1 / 8$ dil. for $40 \%$ strains to $1 / 64$ for $20 \%$ strains and for Esch. coli it was from $1 / 32$ dil. for $70 \%$ strains and $1 / 64$ dil. for $20 \%$ strains. Natarajan et al. (2003) used clinical isolates of dermatophytes (Trichophyton rubrum, Trichophyton mentagrophytes and Microsporum nanum) were treated with extracts of leaves and seeds of the plant Azadirachta indica, (Neem) for antifungal activity in vitro by tube dilution technique and found the MIC of neem seed extracts was $31 \mathrm{mg} / \mathrm{ml}$. for all the dermatophytes tested. Das et al. (1999) and Parida et al. (2002) reported that Aquaneem, an emulsified product prepared from the neem (A. indica) kernel was tested against four pathogenic bacteria of fish (i.e. Aeromonas hydrophila, Pseudomonas fluorescens, Escherichia coli and Myxobacteria spp.) to test its efficacy as an antibacterial agent. A. hydrophila, P. fluorescens and Myxobacteria spp. exhibited maximum sensitivity to Aquaneem in terms of percentage reduction of bacterial cell population in comparison to $E$. coli.

The MIC of Ceftriaxone against S. aureus was $10 \mu \mathrm{g} / \mathrm{ml}$ in 1:100 dilution of set IV and that against E. coli and $P$. aeruginosa was the same and was $25 \mu \mathrm{g} / \mathrm{ml}$ in 1: 40 dilution of set III (Table 6). Visible growth of S. aureus was observed in 1:200 dil. and 1:1000 dilutions. But the organisms failed to grow in 1:100 dil to 1:10 dilutions. So the minimum inhibitory concentration (MIC) of Ceftriaxone against $S$. aureus was in 1:100 dilution of concentration $10 \mu \mathrm{g} / \mathrm{ml}$. Figure 4 also showed visible growth of $E$. coli and $P$. aeruginosa in 1:100 dil. to 1:1000 dilutions. But the organisms failed to grow in 1:40 dil. to 1:10 dilutions. So the MIC of Ceftriaxone against E. coli and P. aeruginosa was in 1:40 dilution of concentration $25 \mu \mathrm{gm} / \mathrm{ml}$ (Figure 4). Controls-1: containing nutrient broth medium without any bacterial inoculation had no visible growth and Controls-2: containing nutrient broth medium with bacterial inoculation observed their visible growth (Table 6).

Set III of 1: 40dilution of Ceftriaxone was composed of $0.25 \mathrm{ml}$ of stock Ceftriaxone solution mixing with $9.75 \mathrm{ml}(10 \mathrm{ml})$ of nutrient broth medium.

$1 \mathrm{ml}$ stock Ceftriaxone solution contained $1 \mathrm{mg}$ of Ceftriaxone

So, $0.25 \mathrm{ml}$ stock Ceftriaxone solution contained $1 \times 0.25 \mathrm{mg}=0.25 \mathrm{mg}$ of Ceftriaxone

Now, $10 \mathrm{ml}$ of $1: 40$ dilution contained $0.25 \mathrm{mg}$ of Ceftriaxone

So, $1 \mathrm{ml}$ of 1:40 dilutions contained $0.025 \mathrm{mg}$ of Ceftriaxone $=0.025 \times 1000 \mu \mathrm{g}=25 \mu \mathrm{g}$ of Ceftriaxone.

Set IV of 1:100dilution of Ceftriaxone was composed of $0.1 \mathrm{ml}$ of stock Ceftriaxone solution mixing with $9.9 \mathrm{ml}$ of nutrient broth medium $(10 \mathrm{ml})$.

$1 \mathrm{ml}$ stock Ceftriaxone solution contained $1 \mathrm{mg}$ of Ceftriaxone

So, $0.1 \mathrm{ml}$ stock Ceftriaxone solution contained $1 \times 0.1 \mathrm{mg}=0.1 \mathrm{mg}$ of Ceftriaxone

Now, $10 \mathrm{ml}$ of stock Ceftriaxone with NB media of 1:100 dilution contained $0.1 \mathrm{mg}$ of Ceftriaxone.

So, $1 \mathrm{ml}$ of $1: 100$ dilutions contained $0.01 \mathrm{mg}$ of Ceftriaxone $=0.01 \times 1000=10 \mu \mathrm{g}$ of Ceftriaxone. 
Table 6: Ceftriaxone against of Staphylococcus aureous, Escherichia coli and Pseudomonas aeruginosa

\begin{tabular}{|c|c|c|c|c|c|}
\hline \multirow[t]{2}{*}{ No. of Sets } & \multirow{2}{*}{$\begin{array}{c}\text { Dilutions of } \\
\text { stock Ceftriaxone }\end{array}$} & \multirow{2}{*}{$\begin{array}{c}\text { Concentrations } \\
\mu \mathrm{g} / \mathrm{ml}\end{array}$} & \multicolumn{3}{|c|}{ Observations } \\
\hline & & & Staphycoccus aureous & Escherichia coli & Pseudomonas aeruginosa \\
\hline Set -I & $1: 10$ & 100 & No growth & No growth & No growth \\
\hline Set - II & $1: 20$ & 50 & No growth & No growth & No growth \\
\hline Set - III & $1: 40$ & $25 *$ & No growth & No growth & No growth \\
\hline Set - IV & 1: 100 & $10 *$ & No growth & growth & growth \\
\hline Set $-\mathrm{V}$ & $1: 200$ & 5 & Growth & Growth & Growth \\
\hline Set - VI & $1: 1000$ & 1 & Growth & Growth & Growth \\
\hline \multicolumn{6}{|c|}{ Controls } \\
\hline Set - VII & Control -1 & $\begin{array}{l}\text { Nutrient broth medium }+ \\
\text { no bacterial inoculation }\end{array}$ & No growth & No growth & No growth \\
\hline Set - VIII & Control -2 & $\begin{array}{l}\text { Nutrient broth medium }+ \\
\text { bacterial inoculation }\end{array}$ & Growth & Growth & Growth \\
\hline
\end{tabular}

* = MIC of Ceftriaxone

The standard antibiotic, Ceftriaxone was sensitive to all of the test organisms. So far less concentrations of Ceftriaxone than that of crude ANLE was required to inhibit the growth of all of the test organisms by broth dilution technique. Also the known MIC of Ceftriaxone $(30 \mu \mathrm{g} / \mathrm{ml})$ was determined by the same broth dilution technique to assess the method that was used to determine the MIC of ANLE. Using broth dilution technique, stock solution of Ceftriaxone of conc. of $1 \mathrm{mg} / \mathrm{ml}$ was diluted to 1:10 dil., 1:20 dil., 1:40 dil., 1:100 dil., 1:200 and 1:1000 dilutions by mixing different amounts of stock Ceftriaxone solution with different amounts of nutrient broth (NB) medium to make the concentrations of the solution 100 $\mu \mathrm{g} / \mathrm{ml}, 50 \mu \mathrm{g} / \mathrm{ml}, 25 \mu \mathrm{g} / \mathrm{ml}, 10 \mu \mathrm{g} / \mathrm{ml}, 5 \mu \mathrm{g} / \mathrm{ml}$ and $1 \mu \mathrm{g} / \mathrm{ml}$ respectively. The culture of Staph. aureus showed visible growth in 1:200 dil and 1:1000 dilution and that failed to grow 1:100 dil to 1:10 dilutions. The minimum inhibitory concentration (MIC) of Ceftriaxone was found in 1.100 dilution of concentration $10 \mu \mathrm{g} / \mathrm{ml}$ against Staph. aureus. Against Esch. coli and Ps. aeruginosa visible growth was found in 1:100 dil to 1:1000 dilutions and that failed to grow in 1:40 to 1:10 dilutions. So, the MIC of Ceftriaxone against both of the organisms was in 1:40 dilution of concentration $25 \mu \mathrm{g} / \mathrm{ml}$.

Results of Comparative study of MICs of ANLE, and Ceftriaxone: MICs of ANLE and Ceftriaxone against S. Aureus were 714 $\mu \mathrm{g} / \mathrm{ml}$, and $10 \mu \mathrm{g} / \mathrm{ml}$ respectively against E. coli and P. aeruginosa MICs of ANLE Ceftriaxone were $1428 \mu \mathrm{g} / \mathrm{ml}, \mathrm{and} 25 \mu \mathrm{g} / \mathrm{ml}$ respectively. So it was observed that MIC of Ceftriaxone was far less than that of ANLE and against all of the test organisms. Against E. coli and P. aeruginosa MICs of ANLE and Ceftriaxone by broth dilution technique were the similar (Table 7). The antibacterial effects of CNLP, ANLE Ceftriaxone on test organisms were bactericidal (i.e killing effects). Otherwise results of subculture study did not similar with that of respective results of experiment I and II. If bacteriostatic action, the visible growth of test organisms might be found in the subculture plates in concentrations at which their inhibitory effects were found in respective culture plates in previous experiments. The materials from last two sets of growth and all sets of no growth of CNLP incorporated into NA media were subcultured in the pure nutrient agar (solid) medium (without any incorporation of CNLP). The results of subculture plates coincided with the respective results of experiments I. The materials from last two sets of growth and all sets of no growth of ANLE and Ceftriaxone preparations were subcultured in the pure nutrient agar (solid) medium (without any NLE or antibiotic). The results of subculture plates coincided with the respective results of experiment II. Natarajan et al. (2003) and Chaturvedi et al. (1978) reported that the MFC was regarded as the lowest concentration of the extract of $A$. indica that prevented the growth of any fungal colony on subculture plates in the solid medium and the MICs and MFCs of ethanol extract, ethyl acetate extract, extract in hexane of neem leaves and seed extract of neem coincided with each other.

Table 7: Comparative study of MICs of ANLE and Ceftriaxone against S. aureous, E. coli and P. aeruginosa

\begin{tabular}{|c|c|c|c|c|}
\hline \multirow{2}{*}{ Sl. no } & \multirow{2}{*}{ MICs of } & \multicolumn{3}{|c|}{ Test organisms } \\
\cline { 3 - 5 } & & Staphycoccus aureous & Escherichia Coli & Pseudomonas aeruginosa \\
\hline I & ANLE & $714 \mu \mathrm{g} / \mathrm{ml}$ & $1428 \mu \mathrm{g} / \mathrm{ml}$ & $1428 \mu \mathrm{g} / \mathrm{ml}$ \\
\hline II & Ceftriaxone & $10 \mu \mathrm{g} / \mathrm{ml}$ & $25 \mu \mathrm{g} / \mathrm{ml}$ & $25 \mu \mathrm{g} / \mathrm{ml}$ \\
\hline
\end{tabular}

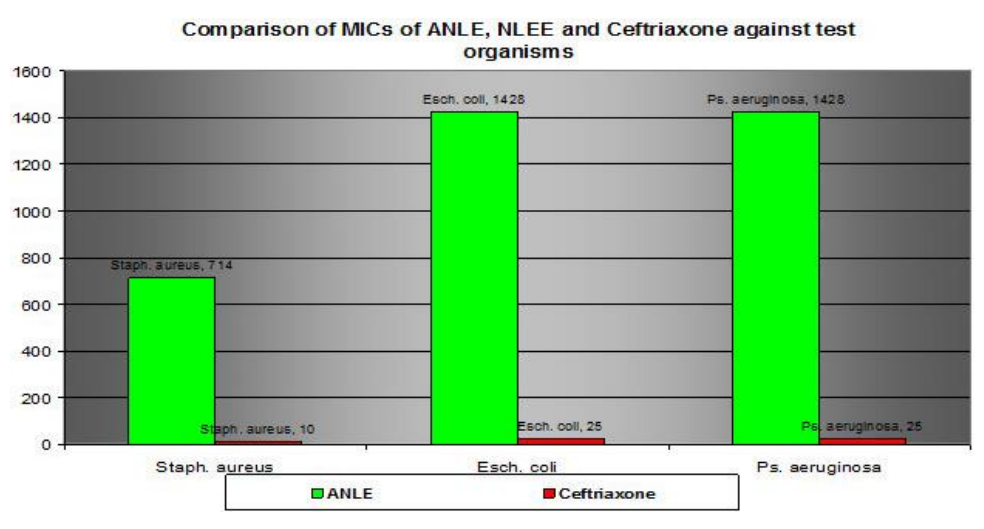


Multiple bar diagram represents the minimum inhibitory concentrations (MICs) of ANLE, NLEE and Ceftriaxone by green, yellow and red bars respectively. The MICs (concentrations: $714 \mu \mathrm{g} / \mathrm{ml}, 666 \mu \mathrm{g} / \mathrm{ml}$ and $10 \mu \mathrm{g} / \mathrm{ml}$ ) of ANLE, NLEE and Ceftriaxone respectively are against $S$. aureus. The MICs of ANLE, NLEE and Ceftriaxone having the concentrations of $1428 \mu \mathrm{g} / \mathrm{ml}, 1332 \mu \mathrm{g} / \mathrm{ml}$ and $25 \mu \mathrm{g} / \mathrm{ml}$ respectively are against E. coli. The MICs (concentrations: $1428 \mu \mathrm{g} / \mathrm{ml}, 1332 \mu \mathrm{g} / \mathrm{ml}$ and $25 \mu \mathrm{g} / \mathrm{ml}$ ) of ANLE, NLEE and Ceftriaxone respectively are against P. aeruginosa.

Table 8: Subculture study of materials from effective CNLP, ANLE and Ceftriaxone in nutrient agar medium for confirmation of respective results of previous experiments

\begin{tabular}{|c|c|c|c|c|c|c|}
\hline \multirow[t]{3}{*}{ Test organisms } & \multicolumn{2}{|c|}{ CNLP } & \multicolumn{2}{|r|}{ ANLE } & \multicolumn{2}{|c|}{ CEFTRIAXONE } \\
\hline & $\begin{array}{l}\text { Inhibitory effects } \\
\text { against growth }\end{array}$ & $\begin{array}{l}\text { No growth in } \\
\text { subculture plates }\end{array}$ & MIC & $\begin{array}{c}\text { No growth in } \\
\text { subculture plates }\end{array}$ & MIC & $\begin{array}{c}\text { No growth in } \\
\text { subculture plates }\end{array}$ \\
\hline & \multicolumn{2}{|c|}{$\mathrm{gm} / 100 \mathrm{ml}$} & \multicolumn{2}{|r|}{$\mu \mathrm{g} / \mathrm{ml}$} & \multicolumn{2}{|r|}{$\mu \mathrm{g} / \mathrm{ml}$} \\
\hline Staphycoccus aureous & $15 \%$ & $15 \%$ & 714 & 714 & 10 & 10 \\
\hline Escherichia coli & $20 \%$ & $20 \%$ & 1428 & 1428 & 25 & 25 \\
\hline Pseudomonas aeruginosa & $25 \%$ & $25 \%$ & 1428 & 1428 & 25 & 25 \\
\hline
\end{tabular}

Results of subculture study of materials from effective CNLP and Ceftriaxone in NA media for confirmation of respective results of previous experiments: The lowest percentages of CNLP showing complete inhibition of growth of S. aureous, E. coli and P. aeruginosa in subculture plates were coincided with previous lowest percentages of CNLP incorporated into NA media showing inhibitory effects against all of the test organisms, Similar results were observed in experiment-I. The minimum inhibitory concentrations (MICs) of ANLE and Ceftriaxone were also coincided with results of their subculture in NA media against all of the test organisms. Similar results were observed in experiment-II (Table 8).

\section{CONCLUSION}

From the study it is clearly observed that there is definite antibacterial effects of aqueous neem leaf extract (ANLE) against Staphylococcus aureus, Escherichia coli and, Pseudomonus aeruginosa. The crude neem leaf paste (CNLP) also have its definite inhibitory effects against all of the organisms studied. But the antibacterial effect of neem leaf extract as covered in the study does not fulfilled the criteria for its therapeutic use, only local application can be adviced. Further study is required to isolate the active ingredients responsible for antibacterial effects of neem leaves and also to know their efficacy, mechanism of action, toxicological aspect and safety margin for its therapeutic use.

\section{ACKNOWLEDGEMENT}

The authors expressed their cordial thanks and gratitude to Prof. AKM Shamsuzzaman, Prof. of Microbiology, CDC, Dghs, Dhaka, who helped too much in different affairs of the research work and writing this scientific article.

\section{REFERENCES}

Chaturvedi DD, Chopra KK and Tumane HM. Neem in Ayurveda: An overview. Neem applications in Agriculture, Health care and Environment. A publication of Neem Foundation 67-A, Vithalnagar, Road no. 12 NS. Juhu Scheme, Mumbai-400 049 India. 1998: 57.

Chaurasia SC and Jain PC. Antibacterial Activity of Essential oils of Four Medicinal plants. Indian J. Hospital Pham Nov - Dec 1978:166-168.

Dahanukar SA, Kulkarni RA, Rege NN. Pharmacology of medicinal plants and natural products. Indian J. Pharmacol. 2000; 32: S81-S118.

Das BK, Mukherjee SC, Sahu BB, Murijani G. Neem (Azadirachta Indica) extract as an antibacterial agent against fish pathogenic bacteria. Indian J. Exp. Biol.[ serial on line] 1999 Nov; 37(11): 1097-100.

Gani A. Bheshaja Oshudh (Herbal Medicine). $1^{\text {st }}$ ed. Bangla Academy; Dhaka, Bangladesh. March 2002: 1-86.

Gani A. Need and importance of using traditional medicine in current perspective of Bangladesh. Hamdard Samachar Dhaka 1205, Bangladesh. 2003; July vol. 3-4. www.hamdard.bd.com

Kabra KN. and Upadhyay V. Development and Ecological Role of Neem in India. The Neem Foundation, Mumbai. Indian Inst. Pub. Administration, I.P. Estate, Ring road, New Delhi-110 002. 2000: 1-15.

Natarajan V, Venugopal PV, Menon T. Effect of Azadirachta indica (Neem) on the growth pattern of Dermatophytes. Indian Journal of Medical Microbiology 2003; 21 (2): 98 - 101.

Neem Tree Farms Company. Advantages of Neem. [Screens 6] Available at: www.neemtreeframs.com Accessed. January 14, 2005.

Parida MM., Upadhyay C, Pandya G, Jana AM Inhibitory potential of neem (Azadirachta Indica Juss) leaves on dengue virus type-2. replication. J. Ethnopharmacol. 2002 Feb; 79(2): 273-8.

Tewari DN. Monograph on Neem. Published in India by RP Singh, International Book Distributors, 9/3, Rajpur Road, Dehra, Dun-248001. India.1992: 1-157.

Upadhyay SN. Neem as a cost effective solution for population control. Neem applications in Agriculture, Health care and Environment. A publication of Neem Foundation. 67-A, Vithalnagar, Road no. 12 NS, Juhu Scheme, Mumbai-400 049. India. $1998: 58$.

$$
-0 \text {-- }
$$

